\title{
Photoreceptor degeneration caused by defects of a ciliary kinase
}

\author{
Y Omori , T Chaya, T Furukawa \\ From First International Cilia in Development and Disease Scientific Conference (2012) \\ London, UK. 16-18 May 2012
}

Defect of ciliary function causes photoreceptor degeneration in human ciliopathies including retinitis pigmentosa (RP), Leber's congenital amaurosis (LCA) and Bardet-Biedl syndrome (BBS). We show that a ciliary kinase, Mak, regulates retinal photoreceptor ciliary length and subcompartmentalization. Mak is localized both in the connecting cilia and outer segment axonemes of photoreceptor cells. In the Mak-null retina, photoreceptors exhibit elongated cilia and progressive degeneration. We observed accumulation of IFT88 and IFT57, expansion of Kif3a in the Maknull photoreceptor cilia. In addition, overexpression of RP1, a microtubule-associated protein localized in outer segment axonemes, induced ciliary elongation, and Mak coexpression rescued excessive ciliary elongation by RP1. Our results suggest that Mak is essential for ciliary protein transport, regulation of ciliary length, acetylation of ciliary microtubules, and is required for the long-term survival of photoreceptors. We are currently studying roles of ciliary kinases in neuronal ciliogenesis.

Published: 16 November 2012

doi:10.1186/2046-2530-1-S1-P96

Cite this article as: Omori et al:: Photoreceptor degeneration caused by defects of a ciliary kinase. Cilia 2012 1(Suppl 1):P96.
Osaka Bioscience Institute, Japan

(c) 2012 Omori et al; licensee BioMed Central Ltd. This is an Open Access article distributed under the terms of the Creative Commons Attribution License (http://creativecommons.org/licenses/by/2.0), which permits unrestricted use, distribution, and reproduction in any medium, provided the original work is properly cited. and take full advantage of:

- Convenient online submission

- Thorough peer review

- No space constraints or color figure charges

- Immediate publication on acceptance

- Inclusion in PubMed, CAS, Scopus and Google Scholar

- Research which is freely available for redistribution 